\title{
PENGALAMAN IBU BEKERJA DALAM PEMBERIAN ASI EKSKLUSIF DI LINGKUNGAN UNIVERSITAS MUHAMMADIYAH MAGELANG
}

\author{
Kartika Wijayanti ${ }^{1}$, Shinta Prawitasari ${ }^{2}$, Wenny Artanty Nisman ${ }^{3}$
}

\begin{abstract}
Background: The percentage of breastfeeding within the last 24 hours is decreasing with increasing age of the baby with the percentage 6 month babies is only about $30.2 \%$. The percentage Central Java reached $34.38 \%$, the low, and became the $6^{\text {th }}$ lowest at Indonesia. This is not met with the government's target of $80 \%$ in 2010. In Magelang district, the number is decreased from $45.18 \%$ in 2011 and $25.6 \%$ in 2012. Total coverage of exclusive breastfeeding at Universitas Muhammadiyah Magelang is $13 \%$.

Objective: To identify employment mother's experience for exclusive breastfeeding at Muhammadiyah Magelang University.

Method: This is a qualitative study, transcendental phenomenological approach. The subjects of this study are employment mother at Muhammadiyah Magelang University who have babies 6-36 months. Data was collected with in-depth interviews, observation, and documentation. Sampling was carried out using purposive sampling technique. Data analysis using 6 stages Colaizzi data analysis. This study began in February 2014 - February 2015.

Result and Discussion: This study resulted 6 categories: employment mother's experiences for exclusive breastfeeding at work less fun, supporting factors of exclusive breastfeeding is complex, mother's knowledge of exclusive breastfeeding is good, physical, technical, and pshycological preparation were necessary to give exclusive breastfeeding, and expectation of the workplace that support for exclusive breastfeeding.

Conclusion: Employment mother's experience for exclusive breastfeeding less fun. Mother's effort to prepare for exclusive breastfeeding such as knowledge, physical, technical, and pshycological. Mother's expectation is workplace that supports exclusive breastfeeding.
\end{abstract}

Keywords: Experience, Employment mother, exclusive breastfeeding

\begin{abstract}
ABSTRAK
Latar Belakang: Cakupan ASI saja dalam 24 jam semakin menurun dengan persentase terendah pada anak umur 6 bulan sebesar 30,2\%. Jawa Tengah 34,38\%, merupakan urutan terendah ke- 6 di Indonesia. Jumlah tersebut belum memenuhi target pemerintah tahun 2010 sebesar $80 \%$. Kabupaten Magelang 45,18\% tahun 2011 dan 25,6\% tahun 2012. Cakupan ASI eksklusif di Universitas Muhammadiyah Magelang sebesar $13 \%$. Tujuan: Mengetahui pengalaman ibu bekerja dalam pemberian ASI Eksklusif di lingkungan Universitas Muhammadiyah Magelang.
\end{abstract}

1 Departemen Keperawatan Maternitas, Fakultas Ilmu Kesehatan Universitas Muhammadiyah Magelang

2 Divisi Obstetri dan Ginekologi Sosial RSUP DR. Sardjito

3 Departemen Keperawatan Maternitas, Fakultas Kedokteran

Universitas Gadjah Mada 
Metode: Desain penelitian ini kualitatif dengan pendekatan fenomenologi transenden. Subyek penelitian ini ibu bekerja di Universitas Muhammadiyah Magelang yang mempunyai bayi usia 6-36 bulan. Pengumpulan data dengan wawancara mendalam, observasi, dan dokumentasi. Tehnik Pengambilan sampel menggunakan purposive sampling. Analisis data menggunakan tahapan analisis data menurut Colaizzi, terdiri dari 6 tahapan. Waktu penelitian Februari 2014 - Februari 2015.

Hasil dan Pembahasan: Penelitian ini menghasilkan 6 kategori yaitu: Pengalaman ibu memerah ASI saat bekerja kurang menyengkan, faktor pendukung ASI eksklusif bersifat komplek, pengetahuan ibu terhadap ASI eksklusif sudah baik, perlu persiapan fisik, tehnis, dan mental untuk memberikan ASI eksklusif, dan harapan terhadap tempat kerja yang mendukung ASI eksklusif.

Kesimpulan: Pengalaman ibu dalam upaya pemberian ASI eksklusif selama bekerja kurang menyenangkan, karena produksi ASI menurun saat ibu bekerja kembali, belum tersedia fasilitas memerah ASI, dan terpaksa memerah di kamar mandi. Upaya yang dilakukan ibu adalah membekali diri dengan pengetahuan tentang ASI eksklusif, memerlukan persiapan fisik, tehnis, dan mental untuk memberikan ASI eksklusif. Harapan ibu adalah tempat kerja yang mendukung ASI eksklusif.

Kata Kunci: Pengalaman, Ibu Bekerja, ASI Eksklusif

\section{PENDAHULUAN}

Jawa Tengah merupakan salah satu dari 9 provinsi yang mengalami peningkatan Angka Kematian Bayi (AKB) pada tahun 2007-2012. AKB di Provinsi Jawa Tengah tahun 2012 sebesar 10,75/1.000 kelahiran hidup, meningkat bila dibandingkan dengan tahun 2011 sebesar 10,34/1.000 kelahiran hidup. ${ }^{1}$ AKB di kabupaten Magelang pada tahun 2012 sebesar 6,75\%, menempati urutan terendah ke-4 dari 35 kabupaten dan kota di provinsi Jawa Tengah, sedangkan AKB di kota Magelang sebesar $16,4 \%$, merupakan urutan tertinggi ke-3 setelah kabupaten Rembang dan Banjarnegara. Terdapat perbedaan yang sangat signifikan antara AKB di kabupaten dan kota Magelang, dan apabila dirata-rata AKB di Magelang sebesar 12,62 per 1.000 kelahiran hidup. ${ }^{1}$

Bayi yang diberi susu formula, memiliki kemungkinan atau peluang untuk meninggal dunia pada bulan pertama kelahirannya 25 kali lebih tinggi dibandingkan dengan bayi yang disusui oleh ibunya secara eksklusif. ${ }^{2}$ Bayi yang diberikan makanan pendamping atau susu selain ASI akan mempunyai risiko 17 kali lebih besar mengalami diare dan 3-4 kali lebih besar kemungkinan terkena Infeksi Saluran Pernafasan Atas (ISPA) dibandingkan dengan bayi yang mendapatkan $\mathrm{ASI}^{3}$

Cakupan pemberian ASI eksklusif di dunia sebesar 32,6\% dari 136,7 juta bayi. Data Survei Demografi dan Kesehatan Indonesia (SDKI) 1997-2007 memperlihatkan terjadinya penurunan prevalensi ASI eksklusif dari 40,2\% pada tahun 1997 menjadi 39,5\% dan 32\% pada tahun 2003 dan 2007. Berdasarkan data hasil Survey Demografi Kesehatan Indonesia/ SDKI (2012) bahwa hanya $27 \%$ bayi umur $4-5$ bulan mendapat ASI eksklusif (tanpa tambahan makanan atau minuman lain). Selain ASI, 8\% bayi pada umur yang sama diberi susu lain dan $8 \%$ diberi air putih.

Cakupan pemberian ASI eksklusif pada bayi $0-6$ bulan di Indonesia menunjukkan penurunan dari 61,5\% tahun 2010 menjadi $61,1 \%$ pada tahun 2011. Cakupan pemberian ASI eksklusif pada bayi sampai usia 6 bulan meningkat 33,6\% padan tahun 2010 menjadi 
38,5\% pada tahun 2011. ${ }^{4}$ Cakupan ASI eksklusif Di Jawa Tengah sebesar 34,38\%, dan angka tersebut merupakan urutan terendah ke-6 di Indonesia. ${ }^{4}$ Cakupan ASI eksklusif di kabupaten/kota Magelang tahun 2012 sekitar 25,6\%, menurun dibandingkan tahun 2011 $(45,18 \%)$.

Universitas Muhammadiyah Magelang merupakan salah satu Perguruan Tinggi di Magelang, dan sepertiga dari jumlah karyawan yang bekerja didalamnya adalah perempuan. Menurut data dari bagian kepegawaian, saat ini terdapat sekitar 67 perempuan yang bekerja di Universitas Muhammadiyah Magelang, dan dari jumlah tersebut, yang sudah menikah dan mempunyai anak sebanyak 59 orang (13\%).

Status ibu bekerja, usia bayi, pemberian makan pra lactal, paritas, dan waktu inisiasi menyusui dini merupakan faktor-faktor yang berhubungan dengan ASI eksklusif secara signifikan. Ibu yang tidak bekerja mempunyai kesempatan untuk memberikan ASI eksklusif $5 x$ lebih banyak dibandingkan dengan ibu yang bekerja. ${ }^{5}$ Kembalinya bekerja dari cuti bersalin bukan menjadi halangan untuk tetap menyusui eksklusif. Keinginan dan motivasi yang kuat dari ibu, dukungan dari suami dan keluarga serta bekal informasi tentang ASI yang cukup akan sangat berpengaruh terhadap keberhasilan menyusui pada ibu bekerja. ${ }^{6}$

Berdasarkan fenomena dan permasalahan tersebut, maka penulis tertarik untuk melakukan penelitian dengan maksud menggali dan mengkaji lebih mendalam tentang makna dan pengalaman ibu bekerja di Universitas Muhammadiyah Magelang dalam upaya pemberian ASI eksklusif.

Air Susu Ibu yang selanjutnya disingkat ASI adalah cairan hasil sekresi kelenjar payudara $\mathrm{ibu}^{7}$. ASI adalah cairan putih yang dihasilkan oleh kelenjar payudara ibu melalui proses menyusui ${ }^{8}$. ASI adalah cairan hidup yang melindungi bayi dari infeksi ${ }^{9}$. Tahun pertama kehidupan bayi, sistem kekebalan bayi belum sepenuhnya berkembang dan tidak bisa melawan infeksi seperti halnya pada anak yang lebih besar atau orang dewasa, maka bayi memerlukan perlindungan dari ibunya. ASI mengandung sel-sel darah putih, dan sejumlah faktor anti infeksi yang dapat melindungi bayi dari infeksi. ${ }^{10}$

Strategi global untuk menyusui bayi dan anak yang masih kecil (Global strategi for infant and young child feeding) merupakan prakarsa dari World Health Organization (WHO) dan United Nations Children Fund (UNICEF) untuk mengembangkan prakarsa sebelumnya yang sukses, khususnya Deklarasi Innocenti dan Baby-Friendly Hospital. Deklarasi Innocenti yang di laksanakan di Florence, Italia pada tahun 1990, merupakan deklarasi perlindungan, peningkatan dan pendukung pemberian ASI eksklusif. Deklarasi tersebut dihadiri oleh 30 negara dan menghasilkan komitmen untuk melindungi hak anak. Dalam declarasi tersebut disebutkan, bahwa ASI eksklusif diberikan pada bayi sampai dengan usia 4 bulan, dan dilanjutkan menyusui sampai dengan 2 tahun. $^{11}$

Undang-Undang Nomor 13 Tahun 2003 tentang Ketenagakerjaan pasal 83 menjelaskan bahwa pekerja/buruh perempuan yang anaknya masih menyusu harus diberi kesempatan sepatutnya untuk menyusui anaknya jika hal itu harus dilakukan selama waktu kerja. Peraturan Pemerintah Nomor 33 Tahun 2012 tentang Pemberian Air Susu Ibu Eksklusif bab II menyatakan bahwa tanggung jawab pemerintah dalam program pemberian ASI Eksklusif pasal (3) huruf e adalah membina, mengawasi, serta mengevaluasi pelaksanaan dan pencapaian program pemberian ASI Eksklusif di fasilitas pelayanan kesehatan, satuan pendidikan 
kesehatan, tempat Kerja, tempat sarana umum, dan kegiatan di masyarakat; pasal (3) huruf h menyediakan ketersediaan akses terhadap informasi dan edukasi atas penyelenggaraan program pemberian ASI Eksklusif.

\section{METODE}

Desain penelitian ini adalah kualitatif yang bertujuan untuk menggali secara mendalam tentang makna dan pengalaman ibu bekerja dalam pemberian ASI eksklusif di lingkungan Universitas Muhammadiyah Magelang. Pendekatan yang digunakan dalam penelitian ini adalah fenomenologi transenden, yaitu pengalaman yang berfokus pada berbagai pengalaman indiviu yang bersifat universal. Pendekatan ini dipilih karena peneliti bermaksud menggali secara mendalam tentang makna, pengalaman, perasaan, upaya, dan harapan ibu bekerja dalam pemberian ASI eksklusif kepada bayinya. Istilah transenden lebih dikenal dengan sebutan fenomenologi deskriptif. ${ }^{12}$

Populasi Subjek dalam penelitian kualitatif disebut dengan partisipan. Jumlah partisipan dalam penelitian ini ditentukan berdasarkan saturasi data, dimana data yang akan didapat dari partisipan tidak terjadi tema atau esensi baru dan hanya mendapatkan pengulangan data dari partisipan. Jumlah partisipan dalam penelitian ini sebanyak 6 orang yang mempunyai bayi usia 6-36 bulan, mempunyai pengalaman menyusui, berhasil maupun tidak berhasil memberikan ASI eksklusif (sejumlah 3 orang partisipan yang berhasil memberikan ASI eksklusif dan 3 orang partisipan yang tidak berhasil memberikan ASI eksklusif), mampu berkomunikasi secara efektif, masih mampu mengingat pengalamannya saat menyusui, serta mampu mengungkapkan pengalamannya dalam upaya pemberian ASI eksklusif. Semua partisipan menyatakan kesukarelaan untuk menjadi partisipan penelitian tanpa ada paksaan, dan tidak ada partisipan yang drop out selama proses penelitian.
Penelitian ini tidak menggunakan istilah populasi. Sampel yang dipilih tidak berdasarkan perhitungan statistik. Sampel yang dipilih berfungsi untuk mendapatkan informasi yang maksimum, bukan untuk digeneralisasikan. Pemilihan partisipan pada penelitian ini menggunakan metode purposive sampling, yaitu tehnik pengambilan sampel dengan memilih individu untuk berpartisipasi dalam penelitian berdasarkan pengetahuan mereka tentang fenomena yang akan diteliti. ${ }^{13}$

Besarnya ukuran sampel pada penelitian ini berjumlah 1-10 orang. ${ }^{12}$ Peneliti melakukan pengumpulan data sampai tidak ada lagi data baru yang didapatkan yang disebut dengan terjadinya saturasi data. Partisipan lain sebagai triangulasi sumber data penelitian adalah kepala bagian Sumber Daya Manusia (SDM) yang membidangi kepegawaian dan administrasi SDM dan Wakil Rektor (WR 2) yang membidangi SDM, sarana prasarana, aset dan keuangan.

Sumber data penelitian kualitatif ini diperolah dengan melakukan wawancara mendalam, alat bantu yang digunakan adalah recorder, model wawancara semi terstruktur dengan pedoman pertanyaan terbuka sebanyak 7 pertanyaan untuk ibu dan 6 pertanyaan untuk pimpinan sebagai triangulasi sumber data. Pedoman wawancara telah dikonsultasikan dengan pembimbing dan sudah dilakukan ujicoba saat latihan wawancara. Pertanyaan tersebut dikembangkan sesuai dengan respon partisipan saat dilakukan wawancara.

Wawancara dilakukan sekitar 40-50 menit berdasarkan pertanyaan yang telah dibuat dalam pedoman wawancara. Peneliti juga menggunakan lembar catatan lapangan (field note) yang menggambarkan respon verbal dan kondisi lingkungan selama proses wawancara, melakukan observasi terkait ketersediaan sarana dan prasarana yang mendukung kebijakan ASI 
eksklusif di tempat kerja menggunakan lembar observasi berupa cheklist Peraturan Menteri Kesehatan Republik Indonesia No 15 Tahun 2013, serta dokumen tentang kebijakan yang berlaku terkait ASI eksklusif.

Teknik/instrument pengumpul data dalam penelitian kualitatif ini, yang menjadi instrument atau alat penelitian adalah peneliti sendiri. Validasi terhadap peneliti sebagai instrumen meliputi validasi terhadap pemahaman metode penelitian kualitatif, penguasaan wawasan terhadap bidang yang diteliti, kesiapan peneliti untuk memasuki objek penelitian, baik secara akademik maupun logistiknya. Evaluasi dilakukan oleh peneliti sendiri, melalui evaluasi diri seberapa jauh pemahaman terhadap metode kualitatif, penguasaan teori dan wawasan terhadap bidang yang diteliti, serta kesiapan dan bekal memasuki lapangan. ${ }^{13}$

Saat ini peneliti bekerja di Universitas Muhammadiyah Magelang, menjadi pembimbing klinik untuk kepeminatan maternitas selama kurang lebih 10 tahun, memperdalam pemahaman ASI eksklusif dengan mengikuti pelatihan konselor menyusui modul 40 jam sesuai standar WHO yang diselenggarakan oleh Universitas Gadjah Mada. Peneliti melakukan latihan wawancara terlebih dahulu sebelum mulai penelitian, hasil wawancara dikonsultasikan dengan pembimbing, untuk melihat kemampuan peneliti dalam melakukan wawancara. Pengambilan data dilakukan setelah konsultasi hasil latihan wawancara dievaluasi dan disetujui oleh pembimbing.

Peneliti menggunakan analisis data menurut Colaizzi untuk fenomenologi yaitu: mendengarkan hasil wawancara, membuat transkrip, membaca transkrip berulang-ulang untuk menemukan pernyataan yang signifikan dari partisipan, selanjutnya pernyataan tersebut menjadi kata kunci (meaning unit). ${ }^{12}$ Kata kunci tersebut selanjutnya dibuat koding, dan koding yang sudah tersusun dikelompokkan menjadi sub kategori. Proses selanjutnya adalah menyusun sub kategori yang sudah didapatkan menjadi kategori. Kategori yang sudah didapatkan lalu dianalisis bersama dengan pembimbing. Kategori yang tersusun, menjadi hasil utama dalam penelitian ini, dan dideskripsikan secara umum dan selanjutnya memaknai data yang ada, sehingga menjadi interpretasi dari makna pengalaman partisipan yang merupakan tujuan penelitian.

\section{HASIL DAN PEMBAHASAN}

Partisipan dalam penelitian ini berjumlah 6 orang semuanya berpendidikan tinggi dengan usia antara 26 - 42 tahun. Jenis pekerjaan partisipan, sebagai dosen berjumlah 3 orang, tenaga kependidikan 2 orang, dan tenaga laboran 1 orang. Penelitian ini menghasilkan 6 kategori yang menggambarkan fenomena pengalaman ibu bekerja dalam pemberian ASI eksklusif di lingkungan Universitas Muhammadiyah Magelang.

Kategori pertama adalah pengalaman ibu memerah ASI saat bekerja kurang menyenangkan, kategori kedua adalah faktor pendukung ASI eksklusif bersifat komplek, melibatkan berbagai pihak, kategori ketiga adalah pengalaman emosional ibu sangat ditentukan oleh berhasil atau tidaknya ibu memberikan ASI eksklusif, kategori keempat adalah pengetahuan ibu terhadap ASI eksklusif sudah baik, kategori kelima adalah perlu persiapan fisik, tehnis dan mental untuk memberi ASI eksklusif, kategori keenam adalah harapan terhadap tempat kerja yang mendukung Asi eksklusif.

Kategori yang dihasilkan tersebut, 3 kategori menjawab tujuan khusus pertama, 2 kategori menjawab tujuan khusus penelitian kedua, dan 1 kategori menjawab tujuan khusus penelitian ketiga. Pengalaman ibu dalam pemberian ASI 
eksklusif saat bekerja kurang menyenangkan yaitu: produksi ASI mulai berkurang saat ibu bekerja kembali, fasilitas memerah ASI belum tersedia di tempat kerja dan memerah di kamar mandi terpaksa dilakukan, seperti dalam kutipan berikut:

" .....ketika sudah bekerja, mungkin karena faktor psikologis dan juga capek begitu....ya jumlahnya menurun....." (R3)

"...disini tidak ada....nyuwun sewu...fasilitas untuk laktasi ya, nggak ada tempat untuk memerah ibaratnya begitu...." (R5)

" ....jadi saya terpaksa memerah di kamar mandi karena tidak ada tempat ya...." (R6)

Faktor pendukung ASI eksklusif bersifat komplek, melibatkan berbagai pihak seperti: motivasi dari dalam diri sendiri, dukungan suami, dukungan anggota keluarga, lingkungan dan rekan kerja, serta menyamakan persepsi dengan pengasuh, seperti dalam cuplikan wawancara berikut :

"...pertama persiapan mental ya buk ya....itu yang paling penting.." (R1)

".....teman-teman sekerja itu sangat memahami posisi saya..dukungan temanteman luar biasa...." (R4)

"....suami saya juga...kalau misalnya stock ASInya menipis, suami saya bersedia untuk datang mengambil ASI ..." (R2)

"...butuh dukungan dari keluraga juga, begitu..." (R6)

".....saya memberikan edukasi dengan ibuk saya..." (R5)

Pengalaman ibu sangat ditentukan oleh berhasil atau tidaknya ibu memberikan ASI eksklusif, seperti cuplikan wawancara berikut ; "......alhamdulillah...walaupun berat....tapi anak saya tetap mendapatkan ASI..." (R2)

"...saya rasanya eman...sebaik-baik buatan manusia, gitu kan masih kalah ya buk... intinya saya eman banget..." (R5).

Upaya ibu bekerja dalam memenuhi kebutuhan ASI eksklusif yang pertama adalah pengetahuan ibu terhadap ASI eksklusif sudah baik, terkait pengertian dan manfaat ASI eksklusif, yang ditunjukkan dengan persepsi ibu.

"...ASI yang diberikan kepada bayi usia 0-6 bulan...belum dikasih apa-apa ya buk...jadi hanya minum air susu ibu saja..." (R1)

"...untuk imun sendiri terbentuk dari ASI tersebut..." (R3)

“....pemberian air susu ibu itu adalah sesuatu yang penting untuk yang pertama mungkin mendukung tumbuh kembang bayi..." (R2)

"...kalau buat saya ya...merasa kedekatan saya dengan anak saya jadi lebih.." (R5)

Upaya kedua adalah perlu persiapan fisik, tehnis dan mental untuk memberi ASI eksklusif, seperti dalam cuplikan waancara berikut :

".....berusaha untuk istirahat yang cukup, kemudian makan eee...secukupnya..saya harus cucui tangan, kemudian saya sbaun, pastikan tangan saya bersih, kemudian payudara juga bersih, kemudian saya kompres dengan air hangat sedikit, sudah.... saya tekan saja..." (R4)

"...saya nyetock ASI..saya beli peralatannya. botol-botol UC kita cuci, kita steril.." (R3)

"......saya usahakan tetap memerah ya.. meskipun hanya sekali saja itu selama bekerja dari pagi sampai sore kerja..saya harus bisa mencari waktu yang memang bener-bener selo...yang agak longgar gitu... 
keburu-buru rasanya juga nggak nyaman.." (R6)

Harapan terhadap tempat kerja yang mendukung ASI eksklusif yaitu: kebijakan umum ada hanya sebatas tertulis saja, kebijakan khusus belum tersedia unutk masing-masing unit, ruangan khusus untuk memerah ASI sangat dibutuhkan ibu, kebijakan pimpinan sangat penting bagi ibu, seperti dalam cuplikan wawancara berikut:

"...kalau kebijakan ...yang legal itu ya...cuti 3 bulan itu buk...memang sudah ada resmi... acc dari universitas..." (R3)

"...kami memang tidak memberithainkan secara khusus tentang peratiran cuti ini, begitu..." (inf.1)

"...kalau yang tidak tertulis itu lebih ke kebijakan yang TST (tahu sama tahu)..jadi.. yang penitng kita bisa melakukan kewajiban kita, tidak meninggalkan tugas, tapi anak juga bisa terpenuhi..." (R4)

"...perlu diberi tempat khusus ya...untuk pojok laktasi..." (R2)

"...yang menyusui itu diberikan waktu free sampai 2 jam.." (R6)

Bulan saat wanita kembali bekerja adalah bulan menyusui yang paling rentan. Kegagalan ibu dalam memberikan ASI eksklusif lebih dari $80 \%$ disebabkan oleh faktor psikologis ibu. Apabila ibu berpikir bahwa ASI perahnya tidak cukup, maka hormon oxytocyn akan bekerja lambat, dan menyebabkan pengeluaran ASI berkurang. ${ }^{14}$ Intensitas menyusui pada wanita yang menyusui langsung bayinya dan yang diperah, hampir sama, sedangkan saat ditempat kerja, baik yang menyusui langsung bayinya maupun yang diperah, waktu keduanya menjadi lebih singkat. ${ }^{15}$

Keberhasilan pemberian ASI eksklusif pada ibu berkerja sangat tergantung dari lingkungan, terutama dukungan dari suami, anggota keluarga lain, rekan sekerja dan komunitas sehingga ibu dapat dengan nyaman memberikan ASI eksklusif serta mengasuh anaknya sambil bekerja. Ada hubungan yang signifikan antara dukungan keluarga dengan praktik pemberian ASI eksklusif. ${ }^{16}$ Dukungan lingkungan tempat bekerja juga penting bagi ibu, karena akan membantu ibu meningkatkan kepercayaan diri untuk menyusui. Support dari teman seperjuangan ini akan membuat ibu mendapatkan komunikasi yang bermanfaat, menyenangkan, dan penting bagi ibu. ${ }^{17}$ Ibu menyusui perlu meningkatkan rasa percaya diri dan motivasi dalam memberikan ASI, menambah pengetahuan tentang pemberian ASI yang benar melalui penyuluhan di tempat pelayanan kesehatan. ${ }^{18} \mathrm{lbu}$ harus sesering mungkin memberikan sentuhan kasih sayang kepada bayinya, karena hal tersebut merupakan sumber kehangatan dan kenyamanan. ${ }^{19}$

Faktor pendukung yang paling penting ibu bekerja dalam memberikan ASI eksklusif adalah motivasi dari diri sendiri, termotivasi secara extrinsik dengan integrated regulation sebagai level motivasi yang paling dominan dimana integrated regulation merupakan motivasi dalam memberikan ASI eksklusif karena nilai, kepercayaan, dan keyakinan Lestari. ${ }^{20}$

Kurangnya dukungan tersebut misalnya kurangnya fasilitas kesehatan pada saat ibu melahirkan, tenaga kesehatan yang membantu persalinan, suami dan keluarga dekat, rekan kerja dan pimpinan di tempat bekerja, tetangga dan masyarakat di sekelilingnya. Selain kurangnya faktor dukungan tersebut, adalah semakin gencarnya promosi produk susu formula. ${ }^{21}$ Memerah di kamar mandi terpaksa dilakukan ibu karena tidak tersedianya fasilitas memerah ASI atau menyusui bayi di tempat kerja. Hal tersebut sesuai dengan penelitian bahwa sekitar 50\% atau satu dari dua pekerja perempuan sektor formal di Jakarta memompa ASI di toilet atau 
di kamar mandi karena kurang memadainya fasilitas ruang laktasi dan tidak adanya program pembinaan laktasi yang maksimal di tempat kerja, sedangkan hal tersebut sudah diamanatkan oleh pemerintah. ${ }^{22}$

Faktor lingkungan yang sangat berpengaruh terhadap perilaku ibu bekerja berasal dari pimpinan perusahaan yang mempunyai kekuasaan untuk membuat kebijakan dan menyediakan fasilitas menyusui selama ibu bekerja. ${ }^{23}$ Ruangan khusus untuk memerah ASI sangat dibutuhkan ibu. Ibu menyusui memberikan keuntungan buan hanya bagi bayi dan ibu saja, akan tetapi juga bagi tempat kerja. Angka absensi ibu pada perusahaan lebih rendah karena anak lebih jarang sakit. ${ }^{24}$ Sebagian besar pimpinan tidak memperhatikan manfaat pemberian ASI eksklusif saat bekerja, seperti mengurangi karyawan tidak masuk kerja karena bayi jarang sakit, dan masih sedikit pimpinan yang membuat aturan tentang menyusui di tempat kerja. ${ }^{25}$

Pengetahuan ibu yang baik mengenai ASI dan bekerja, persiapan ibu yang baik menjelang dan saat bekerja, pengetahuan mengenai memerah ASI, rmemberikan dampak yang besar bagi keberhasilan ibu menyusui. ${ }^{21}$ Penelitian juga menyatakan bahwa terdapat hubungan yang signifikan antara antara tingkat pengetahuan ibu tentang ASI eksklusif dengan perilaku pemberian ASI pada ibu menyusui. Pengetahuan merupakan hasil stimulasi informasi yang diperhatikan, dipahami dan diingat. Informasi dapat berasal dari berbagai bentuk termasuk pendidikan formal maupun non formal, perlakuan harian, membaca, mendengar radio, menonton televisi dan dari pengalaman hidup lainnya. ${ }^{26}$

\section{KESIMPULAN DAN SARAN}

Pengalaman ibu bekerja dalam pemberian ASI eksklusif di lingkungan Universitas Muhammadiyah Magelang secara umum masih kurang menyenangkan menurut persepsi ibu. Upaya yang dilakukan ibu bekerja dalam pemberian ASI eksklusif terdiri dari: membekali diri dengan pengetahuan dan persiapan fisik, tehnis dan mental untuk memberi ASI eksklusif. Harapan ibu adalah adanya kebijakan pimpinan yang mendukung program ASI eksklusif.

Penelitian ini menjadi dasar kebijakan, rencana kerja pimpinan, kerangka pemikiran pimpinan, memfasilitasi tersusunnya peraturan tentang ASI eksklusif secara tertulis, sehingga kebijakan masing-masing unit kerja akan sama.Penelitian akan lebih sempurna apabila melibatkan pihak terkait yang mempunyai wewenang untuk melakukan monitoring dan evaluasi terhadap pelaksanaan kebijakan tentang ASI eksklusif.

\section{DAFTAR PUSTAKA}

1. Dinkes Provinsi Jateng. Profil kesehatan provinsi Jawa Tengah. Semarang. Dinkes Provinsi Jateng. http://www.dinkesjatengprov.go.id. 2012.

2. Edmond, K.M., Zandoh, C., Quigley, M.A., AmengaEtego, S., Seth. Delayed breastfeeding initiation increases risk of neonatal mortality. Official Journal of The American Academy of Pediatrics. http:// pediatrics.aappublications.org. 2006.

3. WHO. Exclusive breastfeeding. http://www.who. int/nutrition/topics/. 2001.

4. Kemenkes RI. Peraturan Menteri Kesehatan RI No. 15 Tahun 2013 tentang tata cara penyediaan fasilitas khusus menyusui dan/atau memerah ASI. Jakarta. Kemenkes RI. www.litbang.depkes.go.id. 2013.

5. Setegn, T., Gerbaba, M., Deribe, K.. factor associated with exclusive breastfeeding practices among mothers in Goba District, south east Ethiopia: a cross-sectional study. http://www.ebscohost.com. 2012

6. Fikawati, S., Syafiq, A. Implementasi dan kebijakan air susu ibu eksklusif dan inisiasi menyusu dini di Indonesia. Makara: Volume 14, No.1. 2010.

7. Peraturan Pemerintah No. 33 tahun 2013 tentang pemberian ASI eksklusif

8. Khasanah, N. ASI atau susu formula ya. Yogyakarta: Flash Books. 2011 
9. WHO. Pelatihan konseling menyusui modul 40 jam. 2011

10. Pillitteri, Adelle. Maternal \& child helath nursing care of the chilebearing \& childbearing family. Philadelphia. Wolter Kluwer, Lippincot; William and Wilkinson. 2010.

11. Innocenti Declaration. 1990-2005. www.innocenti5. net/declaration.pdf

12. Afiyanti,Y., Rachmawati, I.N. Metodologi peneltitian kualitatif dalam riset keperawatan. Jakarta: PT Raja Grafindo Persada. 2014

13. Sugiyono. Metode penelitian kuantitatif kualitatif dan R\&D. Bandung: Alfabeta. 2013

14. Prasetyono. buku pintar ASI eksklusif. pengenalan, praktik, dan kemanfaatan-kemanfaatannya. Jogjakarta: Diva Press. 2012

15. Fein, S.B., Mandal B. Secrest of strategies for combaining employment and breastfeeding. Pediatrics Volume.122. http://pediatrics. aappublications.org. 2008.

16. Elmida, A.S., Djauhar, I. Pengaruh dukungan keluarga dalam pemberian ASI eksklusif pada ibu bekerja di kota langsa. 2011.

17. Ingram, J. A mixed-methods. evaluation of peer support in bristol, uk : mothers midwives and peer supports' view and the effect on breastfeeding. BMC Pregnancy Childbirth. www.ncbi.nlm.gov/ pubmed/24139326. 2013

18. Anggorowati, Nuzulia, F. Hubungan antara dukungan keluarga dengan pemberian asi eksklusif di desa Bebengan Kecamatan Boja kabupaten Kendal. Jurnal Keperawatan Maternitas. Volume 1, No.1. 2013

19. Hegar, B. Nilai menyusui. Jakarta: Badan Penerbit IDAI. 2010

20. Lestari, A.. Motivasi ibu bekerja dalam memberikan ASI eksklusif di PT Dewhirst men's wear Indonesia. Students E-Juornals. Volume 1, No.1 http://jurnal. unpad.ac.id. 2012

21. Wilar, R.Indonesia menyusui. Sukses menyusui saat bekerja. Jakarta: Penerbit IDAI .2010

22. Basrowi, R. Pemberian ASI eksklusif pada perempuan pekerja sektor formal. Jakarta. Tesis. Universitas Indonesia. http://m.kompas.com/ health. 2013

23. Setyawati,I., Sutrisminah,E. Pentingnya motivasi dan persepsi pimpinan terhadap perilaku pemberian ASI eksklusif pada ibu bekerja. Majalah Ilmiah Sultan Agung. Volume 50, No.127. http:// jurnal.unissula.ac.id. 2012.

24. Mills, S.P. Employer attitudes and their intent to support breastfeeding in the work place. The university of graduate school of the university of texas at austin. 2011

25. Arno, J., Broerman, D., Gleason, E., Ward, A.M. Changes in the workplace America. NAEYC. http:// www.naeyc.org/policy/federal/bill-law. 2010

26. Aprilia, Y. Analisis sosialisasi program IMD dan ASI eksklusif kepada bidan di kabupaten Klaten. 2009. 